\title{
PENGARUH IMPLEMENTASI VISI DAN BUDAYA ORGANISASI DALAM PENDIDIKAN TERHADAP MUTU PENDIDIKAN
}

\author{
${ }^{1}$ Reza Aulia Akbar dan ${ }^{2}$ Rukanto \\ ${ }^{1}$ Peneliti Independen Universitas PGRI Palembang \\ ${ }^{2}$ Kepala Sekolah SMA Plus Negeri 2 Banyuasin III \\ e-mail: BUDAKPGRI01@gmail.com
}

\begin{abstract}
The number of competition in the educational world in Indonesia requires educational institutions have value added to be selected and trusted by the community. The added value can be implemented as the quality of education in which the educational institution provides a guarantee of communities' satisfaction as consumer. The quality of institutions should respond to the demand changes occur in society. In order to meet the demand and community needs the educational institutions should be built with an organizational culture that provides strength for the implementation of quality process. This research used quantitative, and the questionnaire was used as instrument. The results of this study indicate that the implementation of vision and culture of healthy organization stimulant can improve the quality of education in YWKA High School of Palembang. In other words, the implementation of vision has a significant impact on the quality of education. Evident from the results of statistical showed that the value of $R$ Square (R2) was 0.985 (98.5\%), the figure illustrates that the percentage contribution of independent variables vision and organizational culture influence $98.5 \%$ while the rest of 1, 5\% influenced by other variable not examined in this research.
\end{abstract}

Keywords: Vision, Organizational Culture, Educational Institutions, Educational Quality.

\section{PENDAHULUAN}

Lingkungan dunia yang mengalami perubahan seperti adanya globalisasi, control masyarakat, perkembangan teknologi, memberikan dampak bagi perkembangan suatu negara maupun bisnis.Pengendalian masyarakat terhadap pelaksanaan kegiatan pemerintahan maupun lembaga pendidikan, sehingga pemerintah tidak dapat membuat kebijakan yang mengabaikan kepentingan masyarakat.Oleh sebab itu dalam menjalankan kegiatannya perlu adanya keselarasan antara kompetensi yang dimiliki lembaga pendidikan maupun pemerintah dengan lingkungan yang ada di luar organisasi (pendidikan dan
pemerintah).Pertimbangan global praktis berdampak pada keputusan strategis.Dengan demikian perlu adanya kegiatan dalam pengambilan keputusan yang disesuaikan antara kemampuan yang dimiliki dengan lingkungan yang ada di sekitar sehingga perlunya adanya manajemen strategi dengan sebuah visi lembaga pendidikan yang selaras untuk mencapai suatu tujuan.

Banyaknya persaingan yang ketat di dunia pendidikan Indonesia saat ini mengharuskan lembaga pendidikan memiliki nilai tambah (value added) yang akan membuat lembaga pendidikanini dipilih dan dipercaya oleh masyarakat. lembaga 
pendidikan harus tanggap terhadap perubahan permintaan yang terjadi dalam masyarakat, sehingga dapat memenuhi permintaan dan kebutuhan pendidikan yang sesuai dengan kebutuhan masyarakat.

Visi adalah sebuah pandangan atau rencana kegiatan pada suatu organisasi pendidikan. Dimana visi di buat biasanya saat sebuah organisasi itu akan dibentuk. Misi merupakan sebuah aktifitas yang mengarah kepada rencana atau tujuan dari sebuah lembaga pendidikan ataupun organisasi yang menjadi sebuah dasar dari sebuah kegiatan lembaga yang menjurus pada sebuah tujuan.

Seiring pesatnya perubahan zaman, termasuk didalamnya perubahan sosial budaya, ekonomi, perkembangan ilmu pengetahuan dan tekhnologi yang secara sistematis menuntut sumber daya manusia yang harus siap menghadapi perubahanperubahan masa depan yang tentunya sangat membutuhkan persaingan sumber daya dalam segala aspek. Oleh karena itu, pendidikan adalah salah satu jawaban segala tantangan kedepan.Sejalan dengan pendapat Umaedi, Hadianto dan Siswantari, (2011: 1.3) yang mengungkapkan bahwa pendidikan berfungsi untuk mempersiapkan manusia menghadapi masa depan agar hidup lebih sejahtera, baik sebagai individu maupun cerara kolektif sebagai warga masyarakat, bangsa maupun antarbangsa. Bagi pemeluk agama, masa depan mencakup kehidupan hari kemudian yang bahagia. dengan demikian, berbagai macam model pendidikan sangat tergantung dari rumusan wujud atau jabaran manusia yang sejartera dengan berbagai dimensinya.

Oleh karena itu, pendidikan harus benar-benar disiapkan dan dikelola sebaikbaiknya agar pendidikan dapat menjadi investasi yang tepat bagi umat manusia untuk menghadapi tuntutan masa kini dan masa kedepannya. Pengelolaan tersebut tentunya harus menyentu segala aspek di dalam pendidikan baik secara makro maupun mikro yang mencakup pengelolaan organisasi di dalam pendidikan, visi dan misi yang kuat dan memiliki tujuan yang jelas, sumber daya manusia di dalamnya serta orientasi pendidikan yang tidak hanya mengedepankan sisi ekonomi dan teknologi semata namun juga pendidikan yang bersifat integritas yang menyunjung tinggi nilai-nilai religius dan budaya sesuai dengan karakter Nusantara.

Organisasi adalah refleksi dari kesadaran dan kedewasaan berfikir manusia bahwa pentingnya berstruktur dalam proses pencapaian tujuan. Di dalamdunia pendidikan organisasi kemudian menjadi subtansi pembahasan sendiri di dalam ilmu pengetahuan dewasa ini yaitu organisasi pendidikan.Sebagaimana dengan apa yang diungkapkan oleh Siagian, (1986: 3), salah satu bentuk dinamika masyarakat pada saat ini 
ialah semakin timbulnya kesadaran bahwa berbagai kebutuhan manusia beradab, baik yang sifatnya fisik material maupun yang wujudnya mental spiritual hanya dapat dipuaskan secara efisien dan efektif melalui berbagai jalur organisasional. Kesadaran demikian pada gilirannya melahirkan berbagai organisasi yang berkecimpung dalam bidang politik, ekonomi, sosial, keagamaan, pendidikan, olahraga dan lain sebagainya.

Dari pendapat diatas, maka dapat diketahui bahwa sebagai alat penggerak roda pendidikan, organisasi di dalam pendidikan di nilai harus dapat menjadi alat manajerial yang harus memiliki fungsi yang signifikan dalam mencapai tujuan pendidikan yang di inginkan dalam setiap jenjang pendidikan. Oleh karena itu, perlu terciptanya budaya organisasi yang baik di dalam organisasi pendidikan di Indonesia.Oleh karena itu sangat penting kiranya untuk mengaplikasikan visi dan budaya organisasi di dalam menuju pendidikan yang matang dan sesuai dengan harapan untuk mencerdaskan bangsa.

\section{TINJAUAN SEPUTAR VISI}

Visi merupakan tahap pertama dalam perencanaan strategis. Pernyataan visi seringkali merupakan kalimat tunggal untuk menjawab ingin menjadi apakah kita dan apa yang ingin kita capai.Menurut kamus bahasa Indonesia, visi yaitu pandangan atau wawasan kedepan, atau kemampuan untuk merasakan sesuatu yang tidak tampak melalui kehalusan jiwa dan ketajaman pengelihatan (Sagono, 2008; 1548).

Sanusi (1995), mengemukakan bahwa visi atau wawasan adalah penglihatan yang mendalam, mengandung pengetahuan (kognitif), kecintaan (afektif), dan kepedulian terhadap profesi serta (konatif).Visi atau wawasan pada dasarnya bukanlah sekadar penglihatan, melainkan suatu penglihatan yang didasari kekuatan mental batiniah dalam cakupan kognitif, afektif, konatif, dan psikomotorik. Visi terbentuk dengan dasar kecerdasan penghayatan nilai-nilai, pengetahuan dan pengalaman, kemampuan khusus yang konseptual pemecahan masalah serta daya-daya perilaku lain yang dijadikan unggulan. Dengan kata lain, visi merupakan intisari endapan dari suatu sistem nilai dan yang diberlakukan. Pendapat yang senada menyatakan bahwa terbentuknya visi dapat dipengaruhi oleh beberapa faktor, di antaranya pengalaman hidup, pendidikan, pengalaman profesional, interaksi dan komunikasi keilmuan serta berbagai kegiatan intelektual lain yang dapat membentuk pola pikir tertentu.

Tripomo dan Udan, (2005: 67) mengemukakan bahwa visi organisasi menggambarkan posisi penting atau peluang besar yang mungkin diraih dimasa depan. lebih lanjut Tripomo dan Udan (2005) 
mengemukakan bahwa ada beberapa hal penting yang perlu diperhatikan tentang pernyataan visi: (1) visi menunjukkan arah strategis; (2) visi lebih menunjukkan apa yang ingin dicapai, buka bagaimana cara mencapainya; (3) seperti pernyataan 'tujuan jangka panjang', visi bisa berupa hasil akhir (misalnya besar pendapatan dan keuntungan, besar pangsa pasar, dsb.), bisa juga berupa kemampuan (misalnya mampu memproduksi biodisel dengan oktan tinggi); (4) visi dan goal berbeda dalam jangka waktu pencapaian. Goal adalah suatu langkah yang harus dicapai dalam jangka waktu tertentu untuk mencapai visi yang diinginkan; (5) visi merupakan representasi dari keyakinan mengenai bagaimanakah seharusnya bentuk organisasi perusahaan dimasa depan dalam pandangan pelanggan, karyawan, pemilik, dan stakeholder lainnya. Selain untuk memacu arah organisasi, pernyataan visi yang baik seringkali mampu membangkitkan semangat, karena anggota organisasi merasayakin bahwa organisasinya memiliki masa depan yang cerah.

Visi tercipta dari kreativitas pikir pemimpin sebagai refleksi profesionalisme dan pengalaman pribadi atau sebagai hasil elaborasi pemikiran mendalam dengan pengikut/personel lain, yaitu tentang ide-ide ideal tentang cita-cita organisasi di masa depan yang ingin diwujudkan bersama (Akdon,
2006:21). Beach (dalam Akdon, 2006: 21) mendefinisikan visi sebagai berikut : "Vision defines the ideal future, perhaps implaying retention of the current culture and the activities, or perhaps implying change".

Masaong, (2011: 93) mengemukakan bahwa visi yang kuat akan menuntut menuju pemimpin yang sukses, karena kepemimpinan yang sukses merupakan kunci keberhasilan organisasi. Organisasi yang sukses adalah organisasi yang mampu melahirkan pemimpinpemimpin dengan komitmen kuat, memiliki visi masa depan, dan mampu menyejahterakan seluruh anggotanya. Lebih lanjut Masaong (2011) mengemukakan bahwa agar menjadi pemimpin yang visioner, maka seorang pemimpin akan berusaha membenahi dan menguasai hal-hal berikut: (1) memahami konsep visi, (2) memahami karakteristik dan unsur visi, (3) memahami tujuan visi, (4) visi yang baik memiliki tujuan utama, (5) mengevaluasi visi.

Dalam mengembangkan visi, pemimpin diharapkan mampu mendayagunakan kekuatan-kekuatan yang relevan bagi kegiatan internal organisasi. Kekuatan-kekuatan tersebut, menurut Hoyle, dapat dibagi ke dalam dua kelompok. Pertama, kekuatan yang berhubungan dengan apa yang sedang berlangsung di luar organisasi pendidikan, seperti munculnya kebijakan pendidikan nasional maupun lokal. Kedua, 
kekuatan yang berhubungan dengan klien pendidikan yaitu, latar belakang sosial, aspirasi keluarga, sumber-sumber masyarakat, karakteristik ketenaga kerjaan, dan lain sebagainya. Pemimpin yang hendak mengembangkan visi organisasi pendidikan, harus menyeleksi secara berkelanjutan atas kelompok-kelompok kekuatan itu (Anwar, 2013: 27).

Dari uraian dan pendapat para ahli diatas maka dapat disimpulkan bahwa visi merupakan dasar dari tujuan yang ingin dicapai.Visi juga merupakan landasan untuk mencapai keberhasilan yang hendak dituju sebagai perwujudan dari hasil kerja keras dan dengan semangat kerjasama yang tinggi dari semua pihak (stakeholder) sesuai dengan tugas dan tanggung jawabnya masing-masing.Di dalam menyusun visi, hal pertama yang harus dilakukan adalah mengidentifikasi apakah keinginan dan impian yang ingin dicapai oleh organisasi baik itu perusahaan maupun lembaga-lembaga formal. Selain itu peran pemimpin sangat dominan dan sangat dibutuhkan untuk menyusun visi bukan hanya karena seorang pemimpin adalah sosok yang memiliki wewenang mengambil keputusan tetapi seorang pemimpin diharapkan memiliki pengetahuan dan pengalaman yang sangat luas dalam kunci keberhasilan organisasi melalui perwujudan visi. Untuk penyusunan visi sekolah bukan hal yang mudah, perlu kajian yang mendalam dan melibatkan semua stakeholders sehingga apa yang diinginkan tercakup didalamnya, Kedua, Visi sekolah memuat banyak hal yang besar seperti tujuan yang ingin dicapai sampai hal yang kecil namun sangat urgen seperti anggaran tahunan, semua ini harus direncakan dengan sebaikbaiknya sehingga dalam pelaksanaan identitas sebuah sekolah dapat terlihat hanya dengan membaca visi dan misi nya, Ketiga, dalam tatanan praktis penyusunan visi bukan hal yang mudah walaupun semua stakeholders dilibatkan tetapi masih saja kesulitan, oleh karena itu diperlukan supervisi ketika kesulitan ini terjadi, dan Keempat, dalam mewujudkan sekolah yang memiliki kualitas baik perlu direncanakan dan dilakukan rekayasa.

\section{BUDAYA ORGANISASI}

Sebelum membahas budaya organisasi, akan timbul pertanyaan awal pada setiap pembahasan mengenai organisasi yaitu "apakah yang dimaksud dengan organisasi". Pertanyaan ini akan membawa kita kepada suatu jawaban tentang rumusan, definisi, atau uraian deskriftif mengenai apa dan bagaimana organisasi itu. Thompson (dalam Thoha, 1984: 123) menyatakan bahwa "an orgnization is a 'highly' rationalized and impersonal integration of a large number of specialist cooperating to achieve some announced 
specipic objec live". Sedangkan Weber (dalam Thoha, 1984: 124) mengemukakan bahwa suatu organisasi atau kelompok kerjasama ini mempunyai unsur-unsur properties sebagai berikut (1) organisasi merupakan tatahubungan sosial. Dalam hal ini seorang individu melakukan proses interaksi sesamanya di dalam organissi tersebut, (2) organisasi mempunyai batasan-batasan tertentu (bounderies). Dengan demikian seseorang individu yang melakukan hubungan interaksi dengan lainnya tidak di dasarkan atas kemauan sendiri.Akan tetapi mereka dibatasi oleh peraturan-peraturan tertentu, (3) organisasi merupakan suatu kumpulan tata aturan, yang bisa membedakan suatu organisasi dengan kumpulan-kumpulan kemasyarakatan. Tata aturan ini menyusun proses interaksi di antara orang-orang yang berkerja sama di dalamnya, sehingga interaksi tersebut tidak muncul begitu saja, (3) organisasi merupakan suatu kerangka hubungan yang berstruktur yang didalamnya berisi wewenang, tanggung jawab, dan pembagian kerja untuk menjalankan suatu fungsi tertentu. Istilah lain dari unsur ini ialah terdapatnya hirarki (hirarchy). Konsekuensi dari adanya hirarki ini ialah bahwa di dalam organisasi ada pimpinan atau kepala dan bawahan atau staff.

Dari pendapat di atas maka dapat diketahui bahwa organisasi adalah ikatan kerja dengan tujuan yang sama oleh beberapa orang yang bersifat asosiatif, berstruktur berdasarkan wewenang, fungsi dan tanggung jawab masing-masing dan saling berhubungan serta berketergantungan satu dengan yang lainnya seperti jaringan kerja.

Duverger (dalam Anwar, 2013: 36)mengemukakan bahwa istilah "kultur" mengacu kepada keyakinan, ideologi dan mitos,; citra-citra kolektif dan ide suatu komunitas yang merupakan elemen spiritual dan psikologis komunitas; teknologi dan lembaga merupa aspek material dari suatu komunitas. Lebih lanjut Duverger (1993) membagi kebudayaan dalam arti luas "Cultural Entities" dengan kebudayaan dalam arti sempit "keyakinan". Entitas kultur merupakan ide-ide kolektif yang sesuai dengan kenyataan-kenyataan eksternal yang mempunyai eksistensi objektif-fisikal (bumi, manusia peralatan, parlemen, dan sebagainya). Keyakinan adalah: mind (lukisan pikiran) yang terlepas dari ekspresi material yang dipe suatu komunitas.

Untuk suatu pemahaman yang holistik, menurut Kleden (dalam Anwar, 2013 : 36) studi budaya hendaknya meliputi peninjauan terhadap basis material, basis sosial, dan basis mental kognitifnya. Basis material budaya menyangkut hubungan manusia dengan dunia fisik, sedangkan basis sosial budaya berkenaan dengan bentuk-bentuk interaksi antar kelompok. Basis mental kognitif budaya 
melihat hubungan antara suatu kelompok dengan dunia pengetahuan dan dunia nilainilai (mental world) mereka.

Schein (dalam Anwar, 2013: 37) memaknakan budaya organisasi sebagai " $a$ fattern of basec assumptions-invented, discovered or develoved by internal integration thet has worked will enough to be considered valid, and therefore, to be thought to new members as the correct way to perceive, think and feel in relation to these problem". Lebih lanjut Scein (1995) mengumpamakan budaya organisasi sebagai "gunung es". Di permukaan terdapat aspekaspek luar dan terbuka yanf diekspresikan secara formal, seperti tujuan tehnologi, struktur, kebijakan, prosedur, dan sumbersumber keuangan organisasi.Sedangkan di abwah permukaan terdapat aspek-aspek informal dari kehidupan organisasi, yang meliputi persepsi, sikap, perasaan yang dialami bersama, perangkat nilai mengenai sifat manusia, sifat hubungan manusiawi yang dianut bersama.

Mengacu kepada definisi dan perumpamaan Schein, selanjutnya Sathe (1983) mengkonstantasi bahwa budaya organisasi jauh lebih daripada perilaku dan justifikasi. Karena, menurut Sathe, organisasi merupakan "The set of important assumption (often that members of community share in common)". Budaya organisasi membentuk sikap karyawan dan menentukan cara organisasi berinteraksi dengan lingkungannya. Sebagaimana dijelaskan oleh Evans(dalam Anwar, 2013:37) bahwa budaya organisasi mengandung arti kepada siapa dan dengan ana organisasi diarahkan. Dimensi dan indikator budaya organisasi yaitu dimensi disiplin, indikatornya; mengecek daftar hadir, menanyakan apabila bawahan tidak hadir, menanyakan kabar bawahan, menegur apabila ada bawahan yang tidak memakai seragam, mengingatkan bahwahan, dan mewujudkan displin; dimensi bersikap sopan, indikatornya; berdasarkan prosedur dan birokrasi, perbedaan pendapat dalam bekerja, saling memberi nasihat, mengabaikan nilai-nilai dalam kantor, mempertimbangkan prinsip inovatf, berdasarkan orientasi hasil, dan sistem kerja secara kelompok; dimensi bersikap ramah, indikatornya; distribusi tugas, mengadopsi cara-cara baru, kebiasaan kerja di kantor, kebijakan kantor, kompetensi yang kuat, kesempatan untuk meningkatkan pengabdian, hubungan pertemanan, dan aturan yang jelas; dimensi taat aturan, indikatornya; memahami aturan formal, melaksanakan pekerjaan, memperhatikan dengam baik, sanksi yang tegas apabila ada pegawai yang melanggar peraturan, selalu menerima pengarahan, mendukung visi misi kepala daerah, dan menekankan pentingnya efisiensi; dimensi bekerja kelas, indikatornya; berkomitmen pada 
hasil, pengembangan sumber daya manusia, dan memahami rencana strategis yang telah disusun.

Budaya organisasi muncul, berawal atau terbentuk dari: (1)tindakan-tindakan anggota organisasi dan hubungan-hubungan yang mereka bina dari waktu ke waktu (Stoner dan Freeman, 1994); (2) lingkungan (Khandwala, 1976); (3) kombinasi antara hasil dan risiko dimana organisasi beroperasi (Deal dan Kennedy, 1982); dan (4) dream pendiri, value anggota dan dikembangkan melalui sistem (Evans, dalam Anwar, 2013:38).

Dengan mencermati peryataan di atas, maka dapat diketahui bahwa budaya organisasi terdiri dari aspek formal dan informal organisasi tersebut. Pada setiap organisasi memiliki budaya yang berkembang. Budaya yang baik, baik itu dari aspek formal maupun informal tentu akan menjadikan sistem organisasi yang baik dan berjalan dengan lebih efektif, dan begitu juga sebaliknya. Budaya organisasi yang efektif adalah adanya hubungan timbak balik yang sehat di dalam struktur organisasi baik itu menyangkut tentang sistem maupun hubungan personal tiap-tiap anggota organisasi. Mencipatakan budaya organisasi yang sehat, tidak kalah penting dalam lembaga pendidikan. Budaya yang sehat akan menciptakan kesatuan dan semangat dari setiap komponen lembaga pendidikan untuk mencapai tujuannya. Dalam rangka untuk menciptakan budaya organisasi, lembaga harus membuat kegiatan rutin untuk membina hubungan baik di dalam lingkungan sekolah maupun diluar lingkungan sekolah. Kepala sekolah juga membiasakan untuk setiap pendidik dan non pendidik agar selalu membangun budaya kerjasama yang kuat dengan yang bertujuan agar setiap pendidik maupun non pendidik memiliki rasa tanggung jawab dan hubungan yang erat dalam setiap pekerjaan karena saling mebutuhkan satu dengan yang lain.

\section{STRATEGI KOMUNIKASI UNTUK MENGEMBANGKAN VISI ORGANISASI}

Komunikasi merupakan bagian penting dalam mencapai tujuan suatu organisasi.Suatu kemampuan dan keterampilan utama yang diharapkan dari seorang manajer ialah kemampuan untuk berkomunikasi secara efektif. Keterampilan untuk memberlakukan kebijakan, mengusahakan supaya instruksiinstruksinya dapat dipahami dengan jelas dan menyempurnakan pelaksanaan kerja tergantung dari komunikasi yang efektif. Berkomunikasi mengandung arti yang lebih luas dari pada sekedar mengatakan atau menuliskan sesuatu. Di dalamnya juga tercakup suatu pengertian. Tidak akan ada komunikasi apabila anda tidak dapat dimengerti dan kekurangan tersebut merupakan penghalang utama dalam berkomunikasi (Terry, 2009: 144). 
Menurut sudut pandang manajemen, beberapa penyebab dari kegagalan berkomunikasi ialah (1) komunikasi mengandung unsur-unsur yang tidak langsung karena tidak mengungkapkan permasalahan yang sebenarnya; (2) penerimaannya mengadakan interprestasi terhadap komunikasi dalam hubungannya dengan latar belakang pribadi serta pengalaman dan (3) penerimanya harus membaca disposisi ke dalam komunikasi tentang hal-hal yang ingin dihindari atau yang memang diharapkannya (Terry, 2009 : 145).

Pertemuan-pertemuan formal di dalam perusahaan merupakan sarana komunikasi yang sudah umum. Didalam pertemuanpertemuan seperti itu dilakukan pembicaraan untuk mengambilan keputusan-keputusan yang bernilai tinggi, dimana diharapkan partisipasi dari kelompok-kelompokkerja yang akan meneruskan informasi-informasi kepada anggota-anggotanya. Suatu pertemuan akan menjadi penting apabila : (a) direncanakan dan setiap anggota manajemen ikut menentukan tujuan, program dan waktunya; (b) bersifat khusus, di mana permasalahan diajukan dan langsung dibicarakan; (c) digambarkan secara visual, terutama apabila menyangkut suatu konsepsi yang pelik atau menggunakan statistik dan (d) tertulis lengkap, untuk mensuplai data tentang hal-hal yang disetujui dan untuk menetapkan tanggungjawab masingmasing bidang. Laporan-laporan tertulis berfungsi sebagai komunikasi tertulis. Dengan membuat laporan secara tertulis, maka bahan tersebut dapat digunakan untuk refrensi lebih lanjut dan mencakup pula hal-hal yang detail (Terry, 2009: 149).

Untuk pengembangan visi organisasi membutuhkan strategi komunikasi yang efektif agar pengembangan visi organisasi dapat dijalankan oleh segenap anggota organisasi sesuai dengan fungsi, jabatan, wewenang dan tanggung jawab masing-masing. Kunci dari komunikasi yang efekktif dikenal dengan empat (4) C, yakni completeness (kebenaran), clarity (kejelasan), conciseness (kepadatan) dan correctness (kebenaran). Laporan-laporan harus sederhana, corak tulisannya harus alami dan cara penyampaiannya harus mudah diikuti. Kondisi-kondisi di bahwah ini dapat membantu komunikasi menjadi efektif: (1) mengetahui sepenuhnya hal-hal yang ingin dikomunikasikan, (2) berkomunikasi secukupnya, (3) menyadari bahwa komunikasi dapat dirubah distribusinya, (4) gunakan simbol-simbol dan alat visual yang memadai, (5) hati-hati memilih informasi yang dikomunikasikan (Terry, 2009: 150).

Dari peryataan di atas, maka dapat disimpulkan bahwa komunikasi tidak hanya diartikan dalam bentuk formal saja, namun komunikasi adalah pengertian yang harus dibangun dari semua komponen. Komunikasi tidak akan dapat berjalan dengan baik apabila 
masih memiliki "gap" yang menjadi penghalang terbentuknya komunikasi yang efektif. Oleh karena itu bukan hanya kemampuan berkomunikasi akan tetapi diperlukan juga strategi dalam berkomunikasi untuk menciptakan kondisi-kondisi yang baik untuk memperkuat komunikasi. Sedangkan visi merupakan dasar dari tujuan yang ingin dicapai.Visi juga merupakan landasan untuk mencapai keberhasilan yang hendak dituju sebagai perwujudan dari hasil kerja keras dan dengan semangat kerjasama yang tinggi dari semua pihak (stakeholder) sesuai dengan tugas dan tanggung jawabnya masing-masing.Di dalam menyusun visi, hal pertama yang harus dilakukan adalah mengidentifikasi apakah keinginan dan impian yang ingin dicapai oleh organisasi baik itu perusahaan maupun lembaga-lembaga formal. Selain itu peran pemimpin sangat dominan dan sangat dibutuhkan untuk menyusun visi bukan hanya karena seorang pemimpin adalah sosok yang memiliki wewenang mengambil keputusan tetapi seorang pemimpin diharapkan memiliki pengetahuan dan pengalaman yang sangat luas dalam kunci keberhasilan organisasi melalui perwujudan visi.

\section{MUTU PENDIDIKAN}

Pendidikan yang bermutu bukan sesuatu yang terjadi dengan sendirinya, melainkan hasil dari suatu proses pendidikan berjalan dengan baik, efektif dan efesien. Suryadi dan Tilaar (1995:108) mengemukakan bahwa mutu pendidikan merupakan kemampuan sistem pendidikan yang diarahkan secara efektif untuk meningkatkan nilai tambah faktor input agar menghasilkan out put yang setinggitingginya Indikator atau kriteria yang dapat dijadikan tolak ukur mutu pendidikan yaitu hasil akhir pendidikan. Standar nasional standar mutu pendidikan merujuk pada Peraturan Pemerintah Nomor 19 tahun 2005 yang menyatakan bahwa Standar Nasional Pendidikan ( SNP) meliputi: (1) Standar isi, (2) Standar Proses, (3)Standar Kompetensi Lulusan, (4) Standar Pendidikan dan Tenaga Kependidikan, (5) Standar Sarana dan Prasarana, (6) Standar Pengelolaan, (7) Standar Pembiayaan, (8) Standar Penilaian Pendidikan (Departemen Pendidikan dan Kebudayaan, 2003).

\section{METODE PENELITIAN}

Jenis penelitian ini adalah penelitian kuantitatif. Menurut Arikunto (2010:9), penelitian kuantitatif adalah penelitian dengan menggunakan angka sebagai sumber data penelitian.Objek penelitian ini adalah SMA YWKA Kecamatan Kertapati Palembang. Peneliti mengambil SMA YWKA yang bertempat di Kecamatan Kertapati Kelurahan Kertapati Palembang karena jarak sekolah yang relatif mudah ditempuh oleh peneliti dan 
juga sekolah tersebut telah memenuhi kriteria yang mendukung dalam proses penelitian ini.

Instumen dalam penelitian ini adalah angket pada setiap variabel penelitian. Angket yaitu sejumlah pertanyaan tertulis yang digunakan untuk memperoleh informasi dari responden dalam arti laporan tentang pribadinya atau hal-hal yang ia ketahui (Arikunto, 2010: 140). Angket yang digunakan adalah sumber data tertulis dengan cara menyebarkan butir-butir pertanyaan kepada responden dengan 5 alternatif jawaban: $\mathrm{A}=$ Selalu (skor 5), B = sering (skor 4), C = kadang-kadang (skor 3), D = jarang (skor 2), E $=$ tidak pernah $($ skor 1$)$.

Setelah dilakukan uji validitas dan reabilitas dengan menggunakan SPSS 17, pada tiap-tiap variabel penelitian, dan dinyatakan bahwa semua item pertanyaan pada tiap-tiap variabel penelitian valid dan reliabel.Maka angket disebar kepada seluruh responden (sampel) secara keseluruhan. Kemudian hasil penyebaran angket tersebut ditabulasikan untuk mengetahui skor secara keseluruhan. Kemudian dilakukan uji persyaratan pada tiaptiap hasil angket yang telah di rekapitulasi dan diketahui skor secara keseluruhan pada masing masing variabel penelitian.

Langkah selanjutnya yaitu memberikan interpretasi dari nilai $\mathrm{t}$ hitung dengan cara membandingkan nilai $\mathrm{t}$ hitung dengan nilai $\mathrm{t}$ tabel. kriteria pengujian terima $\mathrm{Ha}$ jika $\mathrm{t}$ hitung $<\mathrm{t}$ tabeldan hipotesis Ho ditolak jika $\mathrm{t}$ hitung $>\mathrm{t}$ tabel. Setelah itu dilakukan uji parsial dengan menggunakan rumus uji $f$ dengan menggunakan SPSS 17.00. Tujuannya adalah untuk mengetahui apakah seluruh variabel devenden berpengaruh secara simulutan terhadap variabel indevenden di dalam penelitian ini.

\section{HASIL PENELITIAN DAN PEMBAHASAN}

Uji validitas dalam penelitian ini diujikan dengan menggunakan SPSS 17.00 Corelation Person dengan $\mathrm{N}=45$ dan $\mathrm{r}_{\text {tabel }}=$ $\mathrm{N}-2=43$ (tingkat kepercayaan 5\%) = 0, 294 . Setelah dilakukan uji validitas dengan menggunakan SPSS 17.00 Corelation Person maka hasil uji validitas instrument pada tiaptiap variabel dalam penelitian ini dinyatakan valid. Uji reliabilitas bertujuan untuk menunjukan sejauh mana suatu hasil pengukuran relative konsisten, pengujian reabilitas pada instrument penelitian ini dengan menggunakan rumus alfa cronbach dengan menggunakan SPSS. 17.00. Scale Reability. Hasil pengujian reabilitas pada instrument penelitian ini dinyatakan reliabel karena nilai alfa dari tiap variabel di atas 0,600 .

Uji normalitas dalam penelitian menggunakan SPSS 17.00 Kolmogorov Smirnov.Uji normalitas dilakukan untuk melihat apakah data berdiskusi normal atau 
tidak dan untuk menentukan apakah data layak atau tidak dianalisa. Dari hasil pengujian, diketahui bahwa nilai sig (2 -tailed) Unstandardized Residual adalah 0,788>0,05. Maka dapat disimpulkan bahwa semua data pada seluruh variabel penelitian ini berdistribusi normal.

Dari hasil pengolahan data dengan $\begin{array}{lll}\text { menggunakan program } & \text { SPSS } & 17.00\end{array}$ menunjukan bahwa nilai koefisien regresi untuk variabel $\left(\mathrm{X}_{1}\right)$ adalah 0,194 , dan nilai constant sebesar 3.790 Sehingga, didapatkan persamaan regresi linier berganda sebagai berikut.

$$
\begin{aligned}
& \mathrm{Y}=\alpha+\mathrm{b}_{1} \mathrm{x}_{1}+\mathrm{b}_{2} \mathrm{x}_{2}+\mathrm{e} \\
& \mathrm{Y}=3.790+0,333 \mathrm{x}_{1}++0,585 \mathrm{x}_{2}+\mathrm{e}
\end{aligned}
$$

Dari persamaan regresi tersebut menggambarkan bahwa mutu pendidikan tanpa dipengaruhi oleh visi dan budaya organisasi adalah sebesar 3,790 dan nilai 0,333 merupakan koofisien regresi yang menunjukan bahwa Jika variabel visi $\left(\mathrm{X}_{1}\right)$ bernilai konstan (nol), maka variabel mutu pendidikan (Y)sebesar 0,333, Demikian pula dengan nilai 0,585 , hal ini menunjukan jika adanya upaya penambahan sebesar satu satuan pada variabel budaya organisasi, maka akan ada kenaikan pada variabel mutu pendidikan (Y) sebesar 0,585 atau sebaliknya.

Uji Koefisien Determinasi ini digunakan untuk mengetahui seberapa besar sumbangan variabel bebas, yaitu visi dan budaya organisasi terhadap variabel terikat yaitu mutu pendidikandi SMA YWKA Kecamatan Kertapati Palembang adalah sebagai berikut: bahwa nilai $\mathrm{R}$ Square $\left(\mathrm{R}^{2}\right)$ sebesar $0,985(98,5$ $\%$ ), angka tersebut menggambarkan bahwa persentase sumbangan pengaruh variabel independen terhadap variabel dependen (mutu pendidikan) sebesar 98,5\% sedangkan sisanya yaitu $1,5 \%$ dipengaruhi oleh variabel lain yang tidak diteliti dalam penelitian ini.

Untuk menguji variabel visi $\left(\mathrm{X}_{1}\right)$, variabel Budaya Organisasi $\left(\mathrm{X}_{2}\right)$, terhadap variabel Mutu Pendidikan (Y) secara satu-satu dengan menggunakan uji $t$ sebagai berikut.Berdasarkan hasil analisa data, diketahui bahwa nilai thitung untuk variabel Visi ( $\left.\mathrm{X}_{1}\right)$ terhadap Mutu Pendidikan (Y) adalah sebesar 3,195, sedangkan $t_{\text {tabel }}$ adalah sebesar 2,016 hal ini berarti $t_{\text {hitung }}(3,195)<\mathrm{t}_{\text {tabel }}$ $(1,2,016)$, dengan nilai sig $(0,003) \leq \alpha(0,05)$. dari hasil ini dapat dikatehui bahwa terdapat pengaruh antara variabel visi $\left(\mathrm{X}_{1}\right)$ terhadap variabel Mutu Pendidikan (Y), maka $\mathrm{Ha}_{1}$ di terima.

Berdasarkan hasil analisa data menggunakan SPSS 17.0, diketahui bahwa nilai thitung untuk variabel Budaya Organisasi $\left(\mathrm{X}_{2}\right)$ terhadap variabel Mutu Pendidikan (Y) adalah sebesar 6,209, sedangkan $t_{\text {tabel }}$ adalah sebesar 2,016 hal ini berarti thitung $(6,209)<$ $t_{\text {tabel }}(2,016)$, dengan nilai sig $(0,000) \leq \alpha$ $(0,05)$. Dari hasil ini dapat dikatehui bahwa 
terdapat pengaruh antara variabel Budaya Organisasi $\left(\mathrm{X}_{2}\right)$ terhadap variabel Mutu Pendidikan (Y), maka Ha2di terima.

Untuk menguji variabel Visi $\left(\mathrm{X}_{1}\right)$,dan Budaya Organisasi $\left(\mathrm{X}_{2}\right)$, terhadap variabel Mutu Pendidikan (Y) secara bersama-sama dengan menggunakan uji $F$. Berdasarkan hasil uji Anova, dapat dilihat bahwa nilai $F_{h i t u n g}$ untuk variabel Visi $\left(\mathrm{X}_{1}\right)$ dan variabel Budaya Organisasi terhadap variabel Mutu Pendididkan (Y) adalah sebesar 19.633. Sedangkan $\mathrm{F}_{\text {tabel }}$ dengan taraf nyata $(\mathrm{a})=5 \%$ dengan pembilang $\mathrm{df}_{1}=\mathrm{k}-1=3-1=2$ dan penyebut $\mathrm{df}_{2}=\mathrm{n}-\mathrm{k}=45-3=42$, adalah 3,22 Sedangkan nilai sig $\alpha=0,000$. Pada hasil analisa dikatuhi bahwa $F_{\text {hitung }}(19,633)>F_{\text {tabel }}$ $(3,22)$, dan nilai $\operatorname{sig} \alpha(0,000) \leq 0,05$. berarti dapat disimpulkan bahwa terdapat pengaruh yang signifikan antara visi $\left(\mathrm{X}_{1}\right)$ dan Budaya Organisasi $\left(\mathrm{X}_{2}\right)$ terhadap Mutu Pendidikan (Y), maka $\mathrm{Ha}_{1}$ ditolak Ho1 diterima. Dengan demikian berarti secara simultan hipotesis terbukti dengan kata lain terdapat pengaruh yang signifikan Antara visi $\left(\mathrm{X}_{1}\right)$ dan variabel Budaya Organisasi $\left(\mathrm{X}_{2}\right)$ terhadap Mutu Pendidikan (Y).

Berdasarkan hasil perhirungan dengan program SPSS 17.00 diperoleh Dari persamaan regresi tersebut menggambarkan bahwa Mutu Pendidikan tanpa dipengaruhi oleh Visi dan Budaya Organisasi adalah sebesar 3,790 dan nilai 0,333 merupakan koofisien regresi yang menunjukan bahwa Jika variabel visi $\left(\mathrm{X}_{1}\right)$ bernilai konstan (nol), maka variabel Mutu Pendidikan (Y) sebesar 0,333, Demikian pula dengan nilai 0,585 , hal ini menunjukan jika adanya upaya penambahan sebesar satu satuan pada variabel Budaya Organisasi maka akan ada kenaikan pada variabel kepuasan tamu (Y) sebesar 0,585 atau sebaliknya.

Hal ini menunjukan bahwa implementasi visi dan budaya organisasi yang sehat secara stimulan dapat meningkatkan mutu pendidikan di SMA YWKA Palembang dengan kata lain bahwa implementasi visi sangat memberikan dampak yang siknifikan terhadap mutu pendidikan. Terbukti dari hasil analisis statistik yang dilakukan oleh peneliti menunjukan bahwa nilai $\mathrm{R}$ Square $\left(\mathrm{R}^{2}\right)$ sebesar $0,985 \quad(98,5 \%), \quad$ angka tersebut menggambarkan bahwa persentase sumbangan pengaruh variabel independen visi dan budaya organisasi berpengaruh sebesar $\quad 98,5 \%$ sedangkan sisanya yaitu $1,5 \%$ dipengaruhi oleh variabel lain yang tidak diteliti dalam penelitian ini.

Apabila dilihat dari nilai $t_{\text {hitung }}$ untuk variabel visi $\left(\mathrm{X}_{1}\right)$ terhadap budaya organisasi (Y) adalah sebesar 3,195, sedangkan $t_{\text {tabel }}$ adalah sebesar 2,016 hal ini berarti thitung $(3,195)<t_{\text {tabel }}(1,2,016)$, dengan nilai sig $(0,003) \leq \alpha(0,05)$. dari hasil ini dapat dikatehui bahwa terdapat pengaruh antara visi 
$\left(\mathrm{X}_{1}\right)$ terhadap mutu pendidikan $(\mathrm{Y})$, maka $\mathrm{Ha}_{1}$ di terima. Dan nilai $t_{\text {hitung }}$ untuk variabel budaya organisasi $\left(\mathrm{X}_{2}\right)$ terhadap mutu pendidikan (Y) adalah sebesar 6,209, sedangkan $t_{\text {tabel }}$ adalah sebesar 2,016 hal ini berarti $t_{\text {hitung }}(6,209)<t_{\text {tabel }}(2,016)$, dengan nilai sig $(0,000) \leq \alpha(0,05)$. dari hasil ini dapat dikatehui bahwa terdapat pengaruh antara variabel budaya organisasi $\left(\mathrm{X}_{2}\right)$ terhadap variabel mutu pendidkan (Y), maka $\mathrm{Ha}_{2} \mathrm{di}$ terima.

Pada pengujian secara simulutan dapat diketahui bahwa $F_{\text {hitung }}(19,633)>F_{\text {tabel }}(3,22)$, dan nilai $\operatorname{sig} \alpha(0,000) \leq 0,05$. berarti dapat disimpulkan bahwa terdapat pengaruh yang signifikan antara visi $\left(\mathrm{X}_{1}\right)$ dan variabel budaya organisasi $\left(\mathrm{X}_{2}\right)$ terhadap mutu pendidikan $(\mathrm{Y})$, maka $\mathrm{Ha}_{1}$ ditolak $\mathrm{Ho}_{1}$ diterima.

Penelitian ini sejalan dengan penelitian yang dilakukan oleh irani (2014) dengan hasil penelitian menunjukkan bahwa profil SMAN 10 Fajar Harapan mendeskripsikan visi, misi, tujuan, sasaran dan profil sumber daya sekolah. Implementasi strategi pada SMAN 10 Fajar Harapan dilakukan melalui aktivitas lingkungan internal dan eksternal sekolah yang dideskripsikan melalui struktur organisasi sekolah, teamwork dan pembagian tugas sekolah, hari dan waktu belajar, aset pembiayaan, kurikulum, promosi sekolah, penerimaan siswa baru, budaya sekolah, kode etik, kebijakan sekolah, keberadaan lingkungan geografis, demografis, lingkungan budaya dan apresiasi masyarakat, regulasi pemerintah, perkembangan ilmu pengetahuan dan teknologi, keterlibatan komite sekolah, lembaga mitra, alumni dan implementasi strategik dalam upaya memenuhi standar pendidikan nasional. Pelaksanaan evaluasi pada SMAN 10 Fajar Harapan dilakukan secara terus menerus melibatkan manajemen puncak dan seluruh personil sekolah baik jangka pendek, menengah dan panjang melalui instrumen evaluasi diri sekolah, guru dan Benchmarking untuk meningkatkan kinerja sekolah dan mutu pendidikan.

Penelitian yang dilakukan oleh Zubaidah (2015) dengan hasil penelitian menunjukkan bahwa Budaya sekolah berpengaruh positif terhadap mutu pendidikan sebesar 67,6\% kategori sedang, Motivasi kerja guru berpengaruh positif terhadap mutu pendidikan sebesar 100\% karegori kuat serta. Budaya sekolah dan motivasi kerja guru secara bersama sama berpengaruh positif terhadap mutu pendidikan.

Mahasiswa Magister Administrasi Pendidikan Pascasarjana Universitas Syiah Kuala Banda Aceh. (2014) dengan hasil penelitian (1) Pembinaan disiplin dalam meningkatkan kinerja guru pada SMA Negeri 1 Simeulue Timur Kabupaten Simeulue dengan beriorientasi pada aturan yang telah ditetapkan, baik peraturan perundang- 
undangan maupun peraturan sekolah. Pendekatan pembinaan disiplin guru dilakukan dengan cara bertahap atau berkala, mulai dari menentukan job description, melakukan pendekatan persuasif, mengawasi proses pembelajaran dan membimbing tugas guru, serta memberi sanksi sesuai dengan tingkat pelanggaran. (2) Sistem pemberian motivasi guru dalam meningkatkan kinerjanya dilakukan dengan memberikan insentif yang sifatnya tidak mengikat, pelayanan yang baik, promosi jabatan, kesempatan mengikuti pelatihan, memberikan pelayanan terhadap keselamatan kerja, dan kenyamanan terhadap tugas guru. (3) Faktor-faktor penghambat dalam meningkatkan kinerja guru adalah kurangnya sosialisasi peraturan sekolah, kurangnya koordinasi, tidak efektifnya komunikasi antarpersonil, dan kurangnya keterlibatan komite sekolah dalam pengambilan keputusan/kebijakan sekolah.

\section{KESIMPULAN}

Berdasarkan hasil penelitian pada Palembang menyimpulkan bahwa ada pengaruh Visi $\left(\mathrm{X}_{1}\right)$ dan Budaya Organisasi $\left(\mathrm{X}_{2}\right)$ secara simultan maupun secara parsial terhadap kepuasan konsumen (Y).Dari hasil ini dapat dijelaskan bahwa penerapan visi sekolah dan membangun budaya organisasi yang sehat terbukti sangat berpengaruh terhadap mutu pendidkan yang diukur dari kualitas pendidikan. Di SMA YWKA, setiap perangkat baik itu pendidik maupun non pendidik berusaha dan saling bekerjasama untuk mencapai visi sekolah yaitu mewujudkan kondisi belajar yang kondusif dan dimasa yang akan datang SMA YWKA akan menjadi sekolah unggulan dalam kualitas pembelajaran.

Dengan adanya budaya bekerjasama yang dibangun oleh pihak yayasan YWKA khususnya di SMA YWKA Kecamatan Kertapati Palembang, terbukti sangat efektif dalam meningkatkan kualitas pemebelajaran di SMA YWKA Palembang. Bukan hanya itu, SMA YWKA juga menjadi salah satu SMA yang dipercaya oleh masyarakat sekitar untuk menyekolahkan anaknya. Perkembangan sekolah khususnya SMA YWKA Kecamatan Kertapati Palembang semakin meningkat terbukti setiap tahun jumlah siswa mengalami peningkatan.Hal ini menunjukan bahwa imlementasi visi berjalan dengan baik dan budaya organisasi dapat dibangun dengan baik di SMA YWKA Kecamatan Kertapati Palembang.

\section{DAFTAR PUSTAKA}

Anwar, Moch. Indochi. (2013). Administrasi Pendidikan dan Manajemen Biaya Pendidikan. Jakarta: Raja Grafindo Persada

Akdon. (2006). Strategic Managenent for Educational Management. Bandung: Alfabeta 
Arikunto, Suharsimi. (2010). Prosedur Penelitian: Suatu Pendekatan Praktek. Jakarta: PT. Rineka Cipta.

Fattah, Nanang. (2009). Ekonomi dan Pembiayaan Pendidikan. Bandung: Remaja Rosdakarya

Irani, Ulfah Z. (2014). Implementasi Manajemen Strategik Dalam Upaya Peningkatan Mutu Pendidikan Pada SMAN 10 Fajar Harapan. Jurnal Administrasi Pendidikan ISSN 23020156 Pascasarjana Universitas Syiah Kuala.

Masaong, Abdul Kadim. (2011). Kepemimpinan Berbasis Multiplele Intelligence.Bandung: Alfabeta

Moeljono, Djokosantoso. (2003). Budaya Korporat dan Keunggulan Korporasi. Jakarta: PT. Elex Media Komputindo.

Mahasiswa Magister Administrasi Pendidikan Pascasarjana Universitas Syiah Kuala Banda Aceh. (2014). Budaya Organisasi Dalam Meningkatkan Kinerja Guru Pada SMA Negeri 1 Simeulue Timur. Aceh: Universitas Syiah Kuala Bandah Aceh.

Sagala, Syaiful. (2010). Manajemen Strategik dalam Peningkatan Mutu Pendidikan. Bandung: Alfabeta.

Sagono. (2008). Kamus Besar Indonesia. Jakarta: Pusat Bahasa.

Sanusi, Anwar. (1995). Metode Penelitian Bisnis. Jakarta Salemba Empat.

Siagian, Sondang P. (1986). Analisis Serta Perumusan Kebijakan dan Strategi Organisasi. Jakarta: NV Sapdodadi.
Suryadi, Ace dan Tilaar, H. A.R. (1994). Analisis Kebijakan Pendidikan Suatu Pengantar. Bandung: PT. Remaja Roesda Karya.

Terry, George R. (2009). Prinsip-Prinsip Manajemen. Jakata: Bumi Aksara

Thoha, Miftah. (1990). Dimensi-Dimensi Prima Ilmu Administrasi Negara.Jakarta: Rajawali Pers

Thoha, Miftah. (1990). Prilaku Organisasi. Jakarta: Rajawali

Tirtarahardja, Umar dan La Sulo, S.L. (2008). Pengantar Pendidikan. Jakarta: Rineka Cipta.

Tripomo, Tedjo. (2005). Manajemen Strategi. Bandung: Rekayasa Sains

Tobari. (2015). Membangun Budaya Organisasi Pada Instansi Pemerintahan. Yogyakarta: Deepublish

Umaedi, Hadiyanto, Siswantari. (2011). Manajemen Berbasis Sekolah. Jakarta: Universitas Terbuka.

Undang-undang Nomor 20 Tahun 2003 tentang Sistem Pendidikan Nasional, Balitbang, Depdiknas.

Zubaidah, Siti. (2015). Pengaruh Budaya Sekolah dan Motivasi Kerja Guru Terhadap Mutu Pendidikan di SMK N 1 Pabelan. Jurnal. Jawa Tengah: Universitas Kristen Satya Wacana. 
